\title{
Morphology and Yield parameters and Biochemical analysis of Soybean (Glycine max (L.) Mrr.) Using Gamma rays, EMS and DES treatment
}

\author{
P. Gopinath ${ }^{1}$, P. Pavadai ${ }^{2 *}$ \\ ${ }^{1}$ Research and Development Centre, Bharathiyar University, Coimbatore, India \\ ${ }^{2}$ P.G. \& Research Department of Botany, Periyar Arts College, Cuddalore 607 001, TN, India \\ *E-mail address: indsankar@rediffmail.com
}

\begin{abstract}
Soybean (Glycine max (L.) Merr.) var. Co-1 seeds were treated with physical mutagen namely such as gamma rays and chemical mutagen namely such as Ethyl Methane Sulphonate (EMS) and Diethyl Sulphate (DES). Various concentrations of gamma rays 10, 20, 30, 40, 50 and $60 \mathrm{KR}$, EMS $(0.1,0.2,0.3,0.4,0.5$ and 0.6 $\%)$ and DES $(0.1,0.2,0.3,0.4,0.5$ and $0.6 \%)$. The morphological parameters such as days to first flower, plant height, number of cluster per plant, number of pod per plan, seed yield per plant, number of branches per plant, number of leaves per plant, protein content and oil content increasing with increasing level of some doses gamma rays, Ethyl methane sulphonate and Diethyl sulphate treatment in $\mathrm{M}_{2}$ and $\mathrm{M}_{3}$ generation were carried out. A number of mutants were recorded in $\mathrm{M}_{2}$ and $\mathrm{M}_{3}$ generations for one or more traits viz., plant height, maturity, branching, pigmentation, fruit size and yield were isolated in $\mathrm{M}_{2}$ and $\mathrm{M}_{3}$ generation. Mean for various characters increased at mutagenic treatment than control. The yield parameters like plant height, number of cluster per plant, number of seeds per plant and seed yield per plant were recorded the moderated and high mean value in the $50 \mathrm{KR}$ of gamma rays $0.5 \%$ of EMS and $0.4 \%$ of DES treated population with compared to control plants.
\end{abstract}

Keywords: Soybean; mutagens; Gamma rays; Generation

\section{INTRODUCTION}

Soybean posses a very high nutritional value. It contains about 20 per cent oil and 40 per cent high quality protein (as against 7.0 per cent in rice, 12 per cent in wheat, 10 per cent in maize and 20-25 per cent in other pulses). Soybean protein is rich in valuable amino acid lycine (5\%) in which most of the cereals are deficient. In addition, it contains a good amount of minerals, salts and vitamins (thiamine and riboflavin) and its sprouting grains contain a considerable amount of Vitamin $\mathrm{C}$, Vitamin $\mathrm{A}$ is present in the form of precursor carotene, which is converted into vitamin $\mathrm{A}$ in the intestine. A large number of Indian and western dishes such as bread, 'chapati', milk, sweets, pastries etc., can be prepared with soybean. Wheat flour fortified with soybean flour makes good quality and more nutritious 'chapati'. Soybean oil is used for manufacturing vanaspati ghee and several other industrial products. Soybean is used for making high protein food for children. It is widely used in the industrial production of different antibiotics. Soybean builds up the soil fertility by fixing large amounts of 
atmospheric nitrogen through the root nodules, and also through leaf fall on the ground at maturity. It can be used as fodder; forage can be made into hay, silage etc. Its forage and cake are excellent nutritive foods for livestock and poultry. Soybean being the richest, cheapest and easiest source of best quality proteins and fats and having a vast multiplicity of uses as food and industrial products is sometimes called a wonder crop.

Soybean is one of the important crops of the world. Production of soybean in India at the present time is restricted mainly to Madhya Pradesh, Uttar Pradesh Maharashtra and Gujarat. It is also grown on a small acreage in Himachal Pradesh, Punjab and Delhi. Soybean grows well in warm and moist climate. The climatic requirements for soybean are almost the same as for maize. A temperature of 26.5 to $30^{\circ} \mathrm{C}$ appears to be the optimum for most of the varieties. Soil temperatures of $15.5^{\circ} \mathrm{C}$ or above favors rapid germination and vigorous seedling growth

\section{MATERIALS AND METHODS}

\subsection{Selection of genotype}

The choice of genotype is an important aspect of crop improvement programme through induced mutagenesis. Mutation breeding the difference is due to genotypes of primary important than the mutagens (Gregory, 1960). The crop species to improvement using mutation breeding should therefore be pursed with varieties outstanding in their agronomic fitness for practical breeding programe (Scarascia-mugnozza, 1968).

The dry and dormant seeds of the Soybean (Glycine $\max$ (L.) Mrr.) var. Co1. were obtained from Millet Breeding Station, Tamilnadu Agricultural University, Coimbatore. $\mathrm{M}_{2}$ generation seeds were raised from $M_{1}$ generation, the seeds were collected from different individual mutagenic treatment. Seeds harvested from individual $\mathrm{M}_{2}$ plants were grown as $\mathrm{M}_{3}$ families in the field.

Was treated with physical and chemical mutagens like Gamma rays, Ethyl methane sulphonate and Diethyl sulphate. For inducing mutation, Soybean treated with various concentrations of gamma rays $10,20,30,40,50$ and $60 \mathrm{KR}$, EMS $(0.1,0.2,0.3,0.4,0.5$ and $0.6 \%)$ and DES $(0.1,0.2,0.3,0.4$, 0.5 and $0.6 \%$ ). Two sets containing 200 healthy seeds were treated with Gamma rays, Ethyl methane sulphonate and Diethyl sulphate. to determine the LD50 value. The treated seeds were transferred to Petri dishes containing two layers of moist filter paper for germination. Ten Petri dishes of 20 seeds per treatment were sown and Percentage germination and seedling variations for each treatment were subsequently determined. The treated seeds were then subjected to germination test. Based on the reduced growth of germination to 50 per cent, LD50 value was determined. Three doses of gamma rays around LD50 were fixed for further studies. Thephysical treatments were induced at sugarcane breeding institute (ICAR), Coimbatore. The chemically treated seeds were presoaked in distilled water for $6 \mathrm{hrs}$ to ensure complete hydration of the seeds. The seeds were treated with solution of EMS, DES for duration of $6 \mathrm{hrs}$. The seeds subjected to treatment were sown in the field along with the control in a randomized block design with three replications. A total of 100 seed were sown in each treatment. All the treatments including the control were raised adopting a spacing of $30 \mathrm{~cm}$ in between rows and 20 $\mathrm{cm}$ between plants. All recommended cultural operations namely, irrigation, weeding and plant protection methods were carried out during the crop growth period. 


\subsection{Field observations}

\subsubsection{Days to first flower (days)}

The number of days taken from sowing to first flower was recorded and expressed as number of days to first flower.

\subsubsection{Plant height (cm)}

The height of the plant from the base to the top of the plant of maturity was measured and expressed in $\mathrm{cm}$.

\subsubsection{Number of branches per plant}

Number of branches arising from the main stem were counted and recorded at the maturity.

\subsubsection{Number of leaves per plant}

The number of leaves was counter and recorded as the number of leaves per plants

\subsubsection{Number of clusters per plant}

Total number of clusters at maturity time were counted and recorded as the number of clusters per plant.

\subsubsection{Number of pods per plant} plant.

Total number of pods at maturity time were counted and recorded as the number of pods per

\subsubsection{Number of seeds per plant}

Total number of seeds from individual plant were counted and recorded as the number of seeds per plant.

\subsubsection{Seed yield per plant}

Seed yield was worked out by using digital electronic balance and expressed in grams.

\subsubsection{Number of branches per plant}

Total number of branches from individual plant were counted and recorded as the number of seeds per plant.

\subsubsection{Number of leaves per plant} per plant.

Total number of leaves from individual plant were counted and recorded as the number of seeds 


\subsection{Biochemical studies}

\subsubsection{Seed Protein content (\%)}

Two sets from the same treated plant of eachM $\mathrm{M}_{2}$ and $\mathrm{M}_{3}$ plants were separately collected and ground in a mortar and the extracts were defatted by washing with three changes of cold acetone for 4 to 6 hrs. The acetone was removed by filtration and the extracts were air-dried at room temperature. The proteins from the defatted meal were precipitated with $10 \%$ trichloro-acetic acid and recovered by centrifugation at $5000 \mathrm{rpm}$ for 30 minutes at $40^{\circ} \mathrm{C}$. The protein content was then determined calorimetrically according to the method of Lowry et al., (1951) using bovine serum albumin as standard.

\subsubsection{Seed oil content $(\%)$}

The oil content of the kernel was estimated with petroleum ether in Soxhlet extraction apparatus (Cox and Pearson, 1962).

\section{RESULT AND DISCUSSION}

The present programme was under taken with soybean genotype variety co-I was subject to study the effect of chemical mutagens such as ethylmethane sulphonate and diethylsulphate. The aims to study the frequency, spectrum of chlorophyll mutants, viable mutants, morphological, yield and yield components, protein and oil contents in $\mathrm{M}_{2}$ and $\mathrm{M}_{3}$ generation.

Soybean is the self-pollinated crop, naturally genetic variability is limited. Flower size is very small, very difficult and costly hybridization so alternatively induced mutagenesis is the best method to enlarge genetic variability within short time. It has been found to be an efficient tool to induce variability for both micro and macro mutation in the self-pollinated crop and it is a supplement to conventional breeding methods (Brock, 1971). The previous workers was under taken to induced genetic variability and to screen useful mutants for their use in improvement of soybean (Rawlings et al., 1958; Papa et al., 1961; Hymowitz and Newell, 1981; Kawakita 1955; Hajduch et al., 2000; Dhole et al., 2003; Pavadai and Dhanavel, 2005; Pavadai, 2006 and Arulbalachandran 2006).

The production of higher frequencies cultivated crops to using mutagenesis. The breeding work can be provided by extensive collection of mutants based on productive characters to source of valuable materials. The different breeding objective could be made possible through induced mutagenesis, especially in grain legumes like soybean.

In Indian to successful for breeding programmes (Amarnath et al., 1991; Balakrishna 1991; Geetha, 1994; Maheshwari et al. 2003; Dhole et al., 2003 Jayamala, 2004; Sasi, 2004; Arulbalachandran, 2006; and Pavadai 2006) Pakistan (Inayatullah and Smyth, 1987; Sattar et al., 1990), Brasil (Neto and Alves, 1997; Bione et al., 2002) Spain (Velasco et al., 1999) and China (Yang Shouping et al., 1998).

Only very limited work has been carried out in cultivated soybean. However, much work has been done in other crop likes caster, linseed, peanut, rapseed, safflower, seasame, sunflower, cluster been, bhendi, black gram and green gram, etc. To understand the mutation process and to use the mutation breeding for crop improvement. 


\subsection{Mean performance}

In the present investigation, the mean for different quantitative characters both the positive and negative direction due to mutagenic treatments.

The important growth parameters like number of leaves has been related to both biological and economic yield. The mean of the total number of leaves maximum at 0.5 per cent of EMS treatment. Similar results were also observed in soybean (Balakrishnan, 1991; Geetha, 1994; Padmavathi et al., 1992 Cheng and Chandlee, 1999; Pavadai and Dhanavel 1994 \& 1995; Pavadai 1996). Similar observations were made in other plants like black gram (Deepalakshmi and Anandakumar, 2004 and Arulbalachandran, 2006).

Plant height, number of branches per plant were recorded the positive shift, the maximum mean values were recorded at50 KR gamma rays, 0.5 per cent of EMS and 0.04 per cent of DES treatment (Table- 1). Such observations were reported by previous workers in Soybean (Balakrishnan, 1991, Geetha, 1994; Cheng and Chandlee, 1999; Dhole et al., 2003; Pavadai, 2006). Lentil (Dixt and Dubey, 1985), rice (Logaprakesh et al., 1992) and sesame (Sengupta and Datta, 2004).

In the present study, the mean values recorded a negative and positive shift for the yield and yield components characters such as number of cluster per plant, number of pod per plant, number of seeds per plant and seed yield per plant. The maximum yield parameter were recorded at $50 \mathrm{KR}$ gamma rays and 0.5 per cent of EMS treatments. Such as observation were reported by previous workers in soybean (Papa et al., 1961; Balakrishnan, 1991; Geetha, 1994; Cheng and Chandlee, 1999; Dhole et al., 2003; Pavadai and Dhanavel, 2004 and 2005; Pavadai, 2006). Similar observations were also made in other plants like black gram (Julite Hepziba and Subramanian, 2002; Arulbalachandran, 2006), Cowpea (Odeigah et al., 1998), Okra (Ghai et al., 2004) and Sesame (Sengupta and Datta, 2004).

The protein and oil content were observed in high mean values among the mutagenic treatments (Table- 17,19). Such observation were reported by some previous workers in soybean (Papa et al., 1961; Balakrishnan 1991, Geetha, 1994; Kawakita, 1995; Hajduech et al., 2000; Pavadai 2006), Chickpea (Abo-Hegazi, 1980) and French bean (Prasad and Jha, 1993).

\section{CONCLUSION}

In conclusion, the soybean variety co-1 responded more and more number of viable and economic mutants for higher frequency $50 \mathrm{KR}$ gamma rays, 0.5 per cent EMS and 0.4 per cent DES treatments for more effective than the other mutagenic treatments.

The present investigation that the isolation of early maturity, high yield, protein content and oil content is possible in $50 \mathrm{KR}$ gamma rays, 0.5 percent of EMS and 0.4 per cent of DES treatments. 
Table 1. Effect of Gamma rays, EMS and DES on yield parameters and biochemical content of soybean in $\mathrm{M}_{2}$ generation.

\begin{tabular}{|c|c|c|c|c|c|c|c|c|c|}
\hline Treatment & $\begin{array}{l}\text { Days to first } \\
\text { flower }\end{array}$ & $\begin{array}{c}\text { Plant } \\
\text { height }\end{array}$ & $\begin{array}{c}\text { number of } \\
\text { cluster per } \\
\text { plant }\end{array}$ & $\begin{array}{l}\text { number of } \\
\text { pod per } \\
\text { plant }\end{array}$ & $\begin{array}{l}\text { seed yield } \\
\text { per plant }\end{array}$ & $\begin{array}{c}\text { number of } \\
\text { branches } \\
\text { per plant }\end{array}$ & $\begin{array}{l}\text { number of } \\
\text { leaves per } \\
\text { plant }\end{array}$ & $\begin{array}{l}\text { Protein } \\
\text { contend }\end{array}$ & $\begin{array}{c}\text { Oil } \\
\text { contend }\end{array}$ \\
\hline Control & $35.58 \pm 2.11$ & $74.82=2.92$ & $21.62=1.54$ & $49.62=2.82$ & $10.21=0.97$ & $4.32=0.11$ & $64.27 \pm 1.99$ & $39.56=1.27$ & $19.05=1.71$ \\
\hline $\begin{array}{c}\text { GAMMA } \\
\text { RAYS 10KR }\end{array}$ & $36.32 \pm 2.30$ & $72.51=3.16$ & $22.32=0.89$ & $59.62=1.96$ & $11.64=0.69$ & $4.46 \pm 0.13$ & $69.54=2.56$ & $40.32=1.52$ & $19.37=1.15$ \\
\hline $20 \mathrm{KR}$ & $36.13 \pm 1.58$ & $74.96=2.55$ & $20.81=0.94$ & $60.39=3.71$ & $12.07=0.77$ & $4.51=0.15$ & $73.21=4.17$ & $41.50=1.90$ & $20.22=1.36$ \\
\hline $30 \mathrm{KR}$ & $35.11 \pm 1.56$ & $73.82=2.82$ & $21.37 \pm 1.37$ & $60.55=4.21$ & $11.85=0.96$ & $5.02=0.10$ & $70.42 \pm 3.56$ & $40.75=1.16$ & $20.56=1.05$ \\
\hline $40 \mathrm{KR}$ & $35.03 \pm 1.30$ & $76.99=3.09$ & $24.39=0.99$ & $61.27=2.96$ & $12.39=0.82$ & $5.07 \pm 0.09$ & $75.37 \pm 1.82$ & $40.79=2.37$ & $19.85=0.58$ \\
\hline $50 \mathrm{KR}$ & $33.44 \pm 1.00$ & $78.29=4.52$ & $26.51=1.72$ & $62.21=3.27$ & $13.46=0.82$ & $5.16 \pm 0.27$ & $81.52=4.21$ & $41.71=1.94$ & $21.76=1.02$ \\
\hline $60 \mathrm{KR}$ & $35.11 \pm 1.41$ & $77.31=2.71$ & $20.12=1.01$ & $50.29 \pm 3.11$ & $12.55=1.27$ & $5.02=0.16$ & $61.32=2.37$ & $41.06=2.07$ & $20.22=0.89$ \\
\hline EMS $0.1 \%$ & $35.90 \pm 1.71$ & $74.21 \pm 1.52$ & $20.19 \pm 0.13$ & $45.46 \pm 2.71$ & $9.31 \pm 0.28$ & $3.71 \pm 0.21$ & $56.19 \pm 2.11$ & $38.75 \pm 0.27$ & $18.95 \pm 1.27$ \\
\hline $0.2 \%$ & $36.37 \pm 2.54$ & $70.39 \pm 2.39$ & $17.51 \pm 0.11$ & $40.19 \pm 3.15$ & $10.56 \pm 0.43$ & $3.95 \pm 0.17$ & $50.85 \pm 3.05$ & $39.17 \pm 0.43$ & $20.11 \pm 0.96$ \\
\hline $0.3 \%$ & $37.51 \pm 1.43$ & $72.56 \pm 3.41$ & $18.38 \pm 0.16$ & $42.31 \pm 2.22$ & $12.15 \pm 0.52$ & $4.87 \pm 0.15$ & $54.32 \pm 1.97$ & $39.60 \pm 0.15$ & $20.34 \pm 0.32$ \\
\hline $0.4 \%$ & $33.27 \pm 1.11$ & $78.75 \pm 2.15$ & $21.39 \pm 0.17$ & $49.16 \pm 2.43$ & $13.06 \pm 0.71$ & $5.03 \pm 0.12$ & $62.19 \pm 4.32$ & $38.99 \pm 0.27$ & $20.25 \pm 0.25$ \\
\hline $0.5 \%$ & $34.71 \pm 1.27$ & $80.19 \pm 4.17$ & $24.54 \pm 0.17$ & $57.38 \pm 3.15$ & $14.17 \pm 0.46$ & $5.17 \pm 0.14$ & $60.56 \pm 3.15$ & $41.15 \pm 0.41$ & $21.47 \pm 0.26$ \\
\hline $0.6 \%$ & $32.80 \pm 1.35$ & $82.91 \pm 3.22$ & $26.32 \pm 0.20$ & $62.31 \pm 3.71$ & $12.54 \pm 0.33$ & $4.92 \pm 0.11$ & $67.38 \pm 2.19$ & $41.38 \pm 0.52$ & $21.85 \pm 0.28$ \\
\hline DES $0.1 \%$ & $34.56 \pm 2.04$ & $69.54 \pm 1.11$ & $22.19 \pm 0.09$ & $57.37 \pm 2.65$ & $10.35 \pm 0.27$ & $4.03 \pm 0.09$ & $54.82 \pm 3.16$ & $40.46 \pm 0.39$ & $20.42 \pm 0.18$ \\
\hline $0.2 \%$ & $36.32 \pm 1.96$ & $70.28 \pm 1.43$ & $18.72 \pm 0.14$ & $40.38 \pm 2.82$ & $10.81 \pm 0.54$ & $5.21 \pm 0.17$ & $51.77 \pm 2.38$ & $39.14 \pm 0.38$ & $20.06 \pm 0.35$ \\
\hline $0.3 \%$ & $38.71 \pm 1.37$ & $73.19 \pm 2.37$ & $22.39 \pm 0.14$ & $43.14 \pm 3.05$ & $11.17 \pm 0.97$ & $5.38 \pm 0.23$ & $60.38 \pm 1.81$ & $39.35 \pm 0.27$ & $20.22 \pm 0.29$ \\
\hline $0.4 \%$ & $36.30 \pm 1.41$ & $76.35 \pm 4.15$ & $24.37 \pm 0.13$ & $52.82 \pm 3.42$ & $13.05 \pm 1.11$ & $5.53 \pm 0.16$ & $64.21 \pm 3.41$ & $40.19 \pm 0.33$ & $20.13 \pm 0.38$ \\
\hline $0.5 \%$ & $33.81 \pm 2.06$ & $80.64 \pm 3.81$ & $25.38 \pm 0.15$ & $59.17 \pm 4.05$ & $12.54 \pm 1.05$ & $5.17 \pm 0.22$ & $65.51 \pm 2.56$ & $41.32 \pm 0.62$ & $21.40 \pm 0.16$ \\
\hline $0.6 \%$ & $34.17 \pm 1.85$ & $76.38 \pm 5.62$ & $20.06 \pm 0.11$ & $60.35 \pm 2.81$ & $11.47 \pm 1.02$ & $4.28 \pm 0.21$ & $55.47 \pm 3.15$ & $40.42 \pm 0.56$ & $20.07 \pm 0.42$ \\
\hline
\end{tabular}


Table 2. Effect of Gamma rays, EMS and DES on yield parameters and biochemical content of soybean in $\mathrm{M}_{3}$ generation.

\begin{tabular}{|c|c|c|c|c|c|c|c|c|c|}
\hline Treatment & $\begin{array}{l}\text { Days to first } \\
\text { flower }\end{array}$ & Plant height & $\begin{array}{c}\text { number of } \\
\text { cluster per } \\
\text { plant }\end{array}$ & $\begin{array}{c}\text { number of } \\
\text { pod per } \\
\text { plant }\end{array}$ & $\begin{array}{l}\text { seed yield per } \\
\text { plant }\end{array}$ & $\begin{array}{l}\text { number of } \\
\text { branches } \\
\text { per plant }\end{array}$ & $\begin{array}{c}\text { number of } \\
\text { leaves per } \\
\text { plant }\end{array}$ & $\begin{array}{l}\text { Protein } \\
\text { contend }\end{array}$ & $\begin{array}{c}\text { Oil } \\
\text { Contend }\end{array}$ \\
\hline Control & $36.81 \pm 1.43$ & $70.75 \pm 4.32$ & $21.62 \pm 1.54$ & $49.62 \pm 2.82$ & $10.21 \pm 0.97$ & $4.32 \pm 0.11$ & $64.27 \pm 1.99$ & $37.56 \pm 1.27$ & $18.05 \pm 1.71$ \\
\hline $\begin{array}{l}\text { GAMMA } \\
\text { RAYS } 10 \mathrm{KR}\end{array}$ & $36.99 \pm 1.25$ & $75.66 \pm 2.56$ & $22.32 \pm 0.89$ & $59.62 \pm 1.96$ & $11.64 \pm 0.69$ & $4.46 \pm 0.13$ & $69.54 \pm 2.56$ & $38.32 \pm 1.52$ & $18.37 \pm 1.15$ \\
\hline $20 \mathrm{KR}$ & $35.47 \pm 1.08$ & $76.43 \pm 5.04$ & $20.81 \pm 0.94$ & $60.39 \pm 3.71$ & $12.07 \pm 0.77$ & $4.51 \pm 0.15$ & $73.21 \pm 4.17$ & $38.50 \pm 1.90$ & $19.22 \pm 1.36$ \\
\hline $30 \mathrm{KR}$ & $37.18 \pm 0.69$ & $74.41 \pm 3.98$ & $21.37 \pm 1.37$ & $60.55 \pm 4.21$ & $11.85 \pm 0.96$ & $5.02 \pm 0.10$ & $70.42 \pm 3.56$ & $39.02 \pm 1.16$ & $19.56 \pm 1.05$ \\
\hline $40 \mathrm{KR}$ & $35.24 \pm 0.78$ & $80.71 \pm 2.54$ & $24.39 \pm 0.99$ & $61.27 \pm 2.96$ & $12.39 \pm 0.82$ & $5.07 \pm 0.09$ & $75.37 \pm 1.82$ & $39.13 \pm 2.37$ & $19.85 \pm 0.58$ \\
\hline $50 \mathrm{KR}$ & $34.35 \pm 1.14$ & $81.02 \pm 2.61$ & $26.51 \pm 1.72$ & $62.21 \pm 3.27$ & $13.46 \pm 0.82$ & $5.16 \pm 0.27$ & $81.52 \pm 4.21$ & $39.56 \pm 1.94$ & $18.76 \pm 1.02$ \\
\hline $60 \mathrm{KR}$ & $37.65 \pm 1.22$ & $62.89 \pm 2.78$ & $20.12 \pm 1.01$ & $50.29 \pm 3.11$ & $12.55 \pm 1.27$ & $5.02 \pm 0.16$ & $61.32 \pm 2.37$ & $38.06 \pm 2.07$ & $18.22 \pm 0.89$ \\
\hline EMS $0.1 \%$ & $35.90 \pm 1.71$ & $74.21 \pm 1.52$ & $20.19 \pm 0.13$ & $45.46 \pm 2.71$ & $10.15 \pm 0.41$ & $4.45 \pm 0.15$ & $56.19 \pm 2.11$ & $38.75 \pm 0.27$ & $18.95 \pm 1.27$ \\
\hline $0.2 \%$ & $36.37 \pm 2.54$ & $70.39 \pm 2.39$ & $17.51 \pm 0.11$ & $40.19 \pm 3.15$ & $9.31 \pm 0.28$ & $3.71 \pm 0.21$ & $50.85 \pm 3.05$ & $39.17 \pm 0.43$ & $20.11 \pm 0.96$ \\
\hline $0.3 \%$ & $37.51 \pm 1.43$ & $72.56 \pm 3.41$ & $18.38 \pm 0.16$ & $42.31 \pm 2.22$ & $10.56 \pm 0.43$ & $3.95 \pm 0.17$ & $54.32 \pm 1.97$ & $39.60 \pm 0.15$ & $20.34 \pm 0.32$ \\
\hline $0.4 \%$ & $33.27 \pm 1.11$ & $78.75 \pm 2.15$ & $21.39 \pm 0.17$ & $49.16 \pm 2.43$ & $12.15 \pm 0.52$ & $4.87 \pm 0.15$ & $62.19 \pm 4.32$ & $38.99 \pm 0.27$ & $20.25 \pm 0.25$ \\
\hline $0.5 \%$ & $34.71 \pm 1.27$ & $80.19 \pm 4.17$ & $24.54 \pm 0.17$ & $57.38 \pm 3.15$ & $13.06 \pm 0.71$ & $5.03 \pm 0.12$ & $60.56 \pm 3.15$ & $41.15 \pm 0.41$ & $21.47 \pm 0.26$ \\
\hline $0.6 \%$ & $32.80 \pm 1.35$ & $82.91 \pm 3.22$ & $26.32 \pm 0.20$ & $62.31 \pm 3.71$ & $14.17 \pm 0.46$ & $5.17 \pm 0.14$ & $67.38 \pm 2.19$ & $41.38 \pm 0.52$ & $21.85 \pm 0.28$ \\
\hline DES $0.1 \%$ & $34.56 \pm 2.04$ & $69.54 \pm 1.11$ & $22.19 \pm 0.09$ & $57.37 \pm 2.65$ & $12.54 \pm 0.33$ & $4.92 \pm 0.11$ & $54.82 \pm 3.16$ & $40.46 \pm 0.39$ & $20.42 \pm 0.18$ \\
\hline $0.2 \%$ & $36.32 \pm 1.96$ & $70.28 \pm 1.43$ & $18.72 \pm 0.14$ & $40.38 \pm 2.82$ & $10.35 \pm 0.27$ & $4.03 \pm 0.09$ & $51.77 \pm 2.38$ & $39.14 \pm 0.38$ & $20.06 \pm 0.35$ \\
\hline $0.3 \%$ & $38.71 \pm 1.37$ & $73.19 \pm 2.37$ & $22.39 \pm 0.14$ & $43.14 \pm 3.05$ & $10.81 \pm 0.54$ & $5.21 \pm 0.17$ & $60.38 \pm 1.81$ & $39.35 \pm 0.27$ & $20.22 \pm 0.29$ \\
\hline $0.4 \%$ & $33.81 \pm 2.06$ & $80.64 \pm 3.81$ & $25.38 \pm 0.15$ & $59.17 \pm 4.05$ & $13.05 \pm 1.11$ & $5.53 \pm 0.16$ & $65.51 \pm 2.56$ & $41.32 \pm 0.62$ & $21.40 \pm 0.16$ \\
\hline $0.5 \%$ & $36.30 \pm 1.41$ & $76.35 \pm 4.15$ & $24.37 \pm 0.13$ & $52.82 \pm 3.42$ & $11.17 \pm 0.97$ & $5.38 \pm 0.23$ & $64.21 \pm 3.41$ & $40.19 \pm 0.33$ & $20.13 \pm 0.38$ \\
\hline $0.6 \%$ & $34.17 \pm 1.85$ & $76.38 \pm 5.62$ & $20.06 \pm 0.11$ & $60.35 \pm 2.81$ & $12.54 \pm 1.05$ & $5.17 \pm 0.22$ & $55.47 \pm 3.15$ & $40.42 \pm 0.56$ & $20.07 \pm 0.42$ \\
\hline
\end{tabular}




\section{References}

[1] Amarnath, K.C.N., S.R. Viswanatha and G. Shivashankar, 1991. Genotypic and phenotypic variability and heritability of some quantitative characters in soybean (Glycine max (L.) Merill). Mysore J. Agric. Sci., 25: 26-31.

[2] Arulbalachandran, D. 2006. Effect of Physical and Chemical mutagensis in black gram (Nigna mungo (L.) Hepper Var. VPN-1. Ph.D, Thesis. Faculty of Science, Annamalai University, Annamalai Nagar, Tamil Nadu.

[3] Atta, B.M., M. Ahsan ul Haq, T.M. Sadiq, M. Sadiq, Mahmud ul Hassan and H. Syed, 2003. Induced flower colour mutations in chickpea. Int. Chickpea and Pigeon pea Newsl., 10: 6-7.

[4] Balakrishnan, P.C., 1991. Induced mutagenesis in soybean (Glycine max (L.) Merill). Ph.D. Thesis, Tamil Nadu Agrl. Univ.,

[5] Cheng, T.S. and J.M. Chandlee, 1999. The structural, biochemical and genetic characterization of a new radiation-induced, variegated leaf mutant of soybean (Glycine max (L.) Merr.). Proc. Natl. Sci. Counc., 23(1): 27-37.

[6] Cox, H.E. and D. Pearson, 1962. In: Chemical analysis of foods. Chemical Publishing Co., Inc., New York, p. 420.

[7] Deepalakshmi, A.J. and C.R. Anandakumar, 2003. Efficiency and effectiveness of physical and chemical mutagens in urdbean (Vigna mungo (L.) Hepper). Madras Agric. J., 90 (7-9): 485-489.

[8] Deepalakshmi, A.J. and C.R. Anandakumar, 2004. Frequency and spectrum of viable mutants in $\mathrm{M}_{2}$ generation of blackgram (Vigna mungo (L.) Hepper). Legume Res., 27(3): 201-204.

[9] Dhole, V.J., J.J. Maheshwari and S. Patil, 2003. Studies on mutations induced by EMS in soybean (Glycine max (L.) Merrill). Agric. Sci. Digest., 23(3): 226-228.

[10] Geetha, K., 1994. Studies on induced mutation in two distinct varieties of soybean (Glycine max (L.) Merill). Ph.D. Thesis, Tamil Nadu Agrl. Univ., Coimbatore.

[11]Hymowitz, T. and C.A. Newell, 1981. Taxonomy of the genus Glycine, domestication and uses of soybean. Econ. Bot., 35: 272-288.

[12] Inayatullah, L. and C.S. Smyth, 1987. Effect of gamma irradiation in physico-chemical characteristics of soybean. Nucleus Pakistan, 24(3-4): 31-34.

[13] Jayamala, V., 2004. Induced chemical mutagenesis in greengram (Vigna radiata (L.) Wilczek). M.Phil. (Bot.) Thesis, Annamalai University, Annamalainagar, Tamil Nadu.

[14] Kawakita, V., 1995. High stearic acid soybean mutant induced by X-ray irradiation. Biosci. Biotech. Biochem., 59: 922-933.

[15] Maheshwari, J.J., V.J. Dhole, Shanti Patil and D.R. Rathod, 2003. Radiation induced variability for quantitative characters in soybean. J. Soils and Crops, 13 (2): 314-316.

[16]Pavadai, P. and D. Dhanavel, 2004. Effect of EMS, DES and colchicine treatment in soybean. Crop Res., 28(1-3): 118-120.

[17] Pavadai, P. and D. Dhanavel, 2005. Effect of gamma rays on yield and its components in soybean (Glycine max (L.) Merr. var. CO 1). Crop Res., 30(3): 459-461. 
[18] Pavadai. P 2006. Studies on induced mutagenesis on soybean (Glycine max (L.) Merr.) Ph.D Thesis, Faculty of Science, Annamala University, Annamalai Nagar.

[19] Sasi, A., 2004. Effect of chemical mutagenesis in bhendi (Abelmoschus esculentus (L.) Moench.). M.Phil. Thesis, Annamalai University, Annamalainagar, Tamil Nadu.

[20] Sattar, A., Neelofar and M.A. Akhtar, 1990. Irradiation and germination effects on phytate, protein and amino acids of soybean. Plant Foods Hum. Nutr., 40(3): 185-194.

[21] Velasco, A., B. Perez-Vich and J.M. Fernandez-Martinez, 1999. The role of mutagenesis in the modification of the fatty acid profile of oilseed crops. J. Appl. Genet., 40(3):185-209.

[22] Yang Shouping, G. Yunyi and X. Hanqing, 1998. A genetic and cytomorphological study on the male sterile mutant NJ 89-1 in soybean. Soybean Science, 17(1): 32-38. 